\title{
Hubungan antara Jumlah Kehilangan Gigi dengan Status Gizi pada Lansia di Desa Kolongan Atas II Kecamatan Sonder
}

\author{
Charlene Pioh \\ Krista V. Siagian \\ Lydia Tendean \\ Program Studi Pendidikan Dokter GigiFakultas Kedokteran \\ Universitas Sam Ratulangi Manado \\ Email: charlenepioh@gmail.com
}

\begin{abstract}
Tooth loss is commonly found among elderly and have bad impact on the TMJ, mastication, aesthetics as well as speech function. Due to mastication disorder, the elderly tend to choose certain food which influences their nutritional status. This study was aimed to obtain the relationship between tooth loss and nutritional status based on BMI among the elderly at Kolongan Atas II, Sonder. This was an analytical descriptive study with a cross-sectional design. Population included elderly aged 60-65 years old at Kolongan Atas II, Sonder. Samples were obtained by using total sampling method. The results showed that there were 30 elderlies that fulfilled the inclusion criteria. Tooth loss more than ten teeth was most common among elderly with normal nutritional status followed by those with overweight. Meanwhile, there was no elderly with underweight. The relationship between the tooth loss and nutritional status was tested with the chi-square which resulted in $P$ value of 0.597 . Conclusion: There was no significant relationship between tooth loss and nutritional status among elderly at Kolongan Atas II, Sonder. The elderlies were advised to pay attention to their nutritional status and to use dentures for replacement of their missing teeth.
\end{abstract}

Keywords: tooth loss, nutrient status, elderly

\begin{abstract}
Abstrak. Pada masa lansia sering terjadi kehilangan gigi yang menyebabkan gangguan TMJ, pengunyahan, estetik, dan fungsi bicara. Gangguan pengunyahan pada lansia menyebabkan kecenderungan memilih makanan tertentu yang dapat memengaruhi status gizi. Penelitian ini bertujuan untuk mengetahui hubungan antara kehilangan gigi dengan status gizi berdasarkan IMT pada lansia di Desa Kolongan Atas II Kecamatan Sonder. Jenis penelitian ialah deskriptif analitik dengan desain potong lintang. Populasi penelitian ialah lansia berusia 60-65 tahun di Desa Kolongan Atas II Kecamatan Sonder sedangkan sampel diperoleh menggunakan metode total sampling. Hasil penelitian mendapatkan sebanyak 30 responden yang memenuhi kriteria inklusi. Kehilangan gigi $>10$ gigi terbanyak pada lansia dengan gizi normal diikuti dengan gizi lebih. Tidak didapatkan lansia dengan gizi kurang. Hubungan antara kehilangan gigi dengan status gizi berdasarkan IMT diuji dengan uji chi square dan mendapatkan nilai $P=0,597$. Simpulan: Tidak terdapat hubungan bermakna antara kehilangan gigi dengan status gizi pada lansia di Desa Kolongan Atas II Kecamatan Sonder. Disarankan agar para lansia untuk tetap memperhatikan asupan makanan agar dapat mempertahankan status gizi yang baik dan menggunakan gigi tiruan sebagai pengganti gigi yang hilang.
\end{abstract}

Kata kunci: kehilangan gigi, status gizi, lansia

Lansia (lanjut usia) merupakan tahap akhir dari siklus kehidupan manusia yang tidak dapat dihindari dan merupakan suatu proses pertumbuhan normal yang akan dialami oleh setiap manusia. Pada tahap ini terjadi penurunan fungsi fisik tubuh akibat proses 
degeneratif (penuaan) dan banyak perubahan seiring bertambahnya usia, baik perubahan struktur dan fungsi tubuh, kemampuan kognitif maupun perubahan status mental. ${ }^{1,2}$ Jumlah penduduk lansia di dunia diperkirakan hampir mencapai 600 juta orang dan diproyeksikan menjadi 2 milyar pada tahun 2050. Indonesia termasuk dalam lima besar negara dengan jumlah lanjut usia terbanyak di dunia. Pada tahun 2014 jumlah lansia di Indonesia mencapai 20,24 juta jiwa, setara dengan $8,03 \%$ dari seluruh penduduk. Jumlah lansia perempuan lebih banyak daripada laki-laki, yaitu 10,77 juta lansia perempuan dibandingkan 9,47 juta lansia laki-laki. Berdasarkan data dari Badan Pusat Statistik (BPS) Kota Manado Tahun 2016, jumlah penduduk usia 60-65 tahun sebesar 14.860 jiwa dengan jumlah laki-laki 7.312 jiwa, perempuan 7.548 jiwa dan usia lebih dari 65 tahun yaitu 15.106 jiwa $^{3-6}$

Gigi geligi memiliki fungsi dan peran yang sangat penting bagi kehidupan. Fungsi gigi yaitu untuk mastikasi (pengunyahan), estetik (keindahan), dan fonetik (berbicara). Kesehatan gigi geligi serta jaringan pendukungnya turut menentukan kesehatan rongga mulut secara keseluruhan termasuk kondisi kesehatan secara umum. Keadaan rongga mulut yang buruk menyebabkan terjadinya karies dan penyakit periodontal sehingga terjadi kehilangan gigi. ${ }^{7-9}$

Kehilangan gigi merupakan suatu keadaan ketidakadaan gigi individu dari soketnya yang disebabkan oleh pencabutan karena karies, penyakit periodontal, trauma, dan penyakit sistemik. Kehilangan gigi biasanya terjadi pada lansia dan menyebabkan terganggunya fungsi pengunyahan, fungsi temporomandibular joint (TMJ), dan psikologis yaitu estetika dan fungsi bicara. Kehilangan gigi pada lansia memengaruhi asupan nutrisi karena lansia cenderung memilih makanan yang lunak atau mudah untuk dikunyah sehingga berkurangya nutrisi dan terjadi masalah gizi pada lansia. $^{10,11}$

Masalah gizi pada lansia berkaitan erat dengan asupan makanan dan metabolisme tubuh. Aktivitas fisik, depresi, serta kondisi mental, pengobatan penyakit dan kemunduran biologik merupakan faktor yang dapat memengaruhi kebutuhan gizi pada lansia. Perubahan fisik dan penurunan fungsi organ tubuh pada lansia dapat juga memengaruhi konsumsi dan penyerapan zat gizi sehingga buruknya asupan gizi akan berdampak pada kualitas hidup lansia. Masalah gizi yang sering dijumpai pada lansia yaitu masalah gizi lebih (overweight dan obesitas), dan gizi kurang (kurus). ${ }^{12-14}$

Penelitian ini bertujuan untuk mengetahui hubungan antara pola kehilangan gigi dengan status gizi pada lansia di Desa Kolongan Atas Kecamatan Sonder.

\section{METODE PENELITIAN}

Jenis penelitian ini ialah deskriptif analitik dengan desain potong lintang. Penelitian dilakukan di Desa Kolongan Atas II Kecamatan Sonder pada bulan Juni 2018.

Populasi penelitian ialah lansia di Desa Kolongan Atas II Kecamatan Sonder yang berusia 60-65 tahun. Pengambilan sampel menggunakan metode total sampling. Sampel yang diambil yaitu semua lansia yang memenuhi kriteria inklusi sebanyak 30 orang lansia

Kehilangan gigi pada lansia dikategorikan menjadi tiga, yaitu: 1) Kehilangan $>10$ gigi; 2) Kehilangan 6-10 gigi; dan 3) Kehilangan $<6$ gigi. ${ }^{15}$ Pemeriksaan status gizi dilakukan dengan mengukur tinggi dan berat badan. Pengukuran status gizi yang digunakan yaitu Indeks Massa Tubuh (IMT). ${ }^{16}$ IMT diperoleh dari perbandingan berat badan (BB) dalam kilogram dan tinggi badan (TB) dalam meter kuadrat. Kategori status gizi lansia berdasarkan IMT menurut Depkes RI tahun 2005 ialah: 1) Gizi kurang $<18,5 \mathrm{~kg} / \mathrm{m}^{2}$; 2) Gizi normal $18,5-25 \mathrm{~kg} / \mathrm{m}^{2}$; dan 3) Gizi lebih >25 $\mathrm{kg} / \mathrm{m}^{2}$.

Data yang diperoleh diolah dan dianalisis menggunakan program statistical package for the social scienses (SPSS) untuk mengetahui hubungan antara kehilangan gigi dengan status gizi. Data yang diperoleh disajikan dalam bentuk tabel. 
Pioh, Siagian, Tendean: Hubungan antara jumlah kehilangan gigi ...

\section{HASIL PENELITIAN}

Desa Kolongan Atas II merupakan salah satu desa yang berada di Kecamatan Sonder, Kabupaten Minahasa, Provinsi Sulawesi Utara. Desa Kolongan Atas II memiliki 7 jaga dengan total jumlah penduduk berjumlah 700 jiwa. Desa Kolongan Atas II bersebelahan dengan desa Leilem Kecamatan Sonder dan desa Kiawa Kecamatan Kawangkoan.

Responden penelitian ini yaitu lansia yang berusia 60-65 tahun di Desa Kolongan Atas II Kecamatan Sonder sebanyak 30 orang yang bervariasi dalam usia dan jenis kelamin. Tabel 1 menunjukkan bahwa responden yang paling sedikit ialah yang berusia 61 tahun $(3,3 \%)$ dan yang terbanyak ialah yang berusia 65 tahun $(40 \%)$.

Tabel 1. Distribusi karakteristik responden berdasarkan usia

\begin{tabular}{ccc}
\hline $\begin{array}{c}\text { Usia } \\
\text { (tahun) }\end{array}$ & n & $\begin{array}{c}\text { Persentase } \\
(\%)\end{array}$ \\
\hline 60 & 7 & 23,4 \\
61 & 1 & 3,4 \\
62 & 2 & 6,6 \\
63 & 6 & 20 \\
64 & 2 & 6,6 \\
65 & 12 & 40 \\
Total & 30 & 100 \\
\hline
\end{tabular}

Tabel 2 menunjukkan bahwa terdapat 10 responden $(33,4 \%)$ berjenis kelamin laki-laki dan 20 responden $(66,6 \%)$ berjenis kelamin perempuan.

Tabel 3 menyajikan hasil pemeriksaan jumlah kehilangan gigi yaitu terbanyak pada kategori $>10$ gigi $(70 \%)$ dan sebagian besar kehilangan gigi di bagian posterior. Yang paling sedikit ialah untuk kategori kehilangan $<6$ gigi $(3,3 \%)$.

Tabel 2. Distribusi karakteristik responden berdasarkan jenis kelamin

\begin{tabular}{ccc}
\hline $\begin{array}{c}\text { Jenis } \\
\text { kelamin }\end{array}$ & n & $\begin{array}{c}\text { Persentase } \\
(\boldsymbol{\%})\end{array}$ \\
\hline Laki-laki & 10 & 33,4 \\
Perempuan & 20 & 66,6 \\
Total & 30 & 100,0 \\
\hline
\end{tabular}

Tabel 3. Distribusi responden berdasarkan kategori kehilangan gigi

\begin{tabular}{ccc}
\hline $\begin{array}{c}\text { Kehilangan } \\
\text { gigi }\end{array}$ & n & $\begin{array}{c}\text { Persentase } \\
(\boldsymbol{\%})\end{array}$ \\
\hline$>10$ gigi & 21 & 70 \\
6-10 gigi & 8 & 26,7 \\
< 6 gigi & 1 & 3,3 \\
Total & 30 & 100 \\
\hline
\end{tabular}

Tabel 4 menunjukkan bahwa lansia berusia 65 tahun terbanyak pada kategori kehilangan $>10$ gigi yaitu 8 orang $(26,6 \%)$ diikuti oleh lansia berusia 63 tahun yaitu orang $(20 \%)$.

Tabel 5 menunjukkan bahwa lansia ber jenis kelamin laki-laki yang terbanyak pada kategori kehilangan gigi $>10$ gigi sebanyak 7 orang $(23,3 \%)$ sedangkan pada perempuan sebanyak 14 orang $(46,7 \%)$.

Pemeriksaan dan penilaian status gizi menggunakan Indeks Massa Tubuh (IMT). Tabel 6 menunjukkan bahwa terdapat 12 orang $(40,0 \%)$ memiliki status gizi lebih, 18 orang $(60,0 \%)$ memiliki status gizi normal, dan tidak terdapat gizi kurang.

Tabel 4. Distribusi jumlah gigi yang hilang berdasarkan usia

\begin{tabular}{|c|c|c|c|c|c|c|c|c|}
\hline \multirow{3}{*}{$\begin{array}{l}\text { Usia } \\
\text { (tahun) }\end{array}$} & \multicolumn{6}{|c|}{ Jumlah gigi yang hilang } & \multicolumn{2}{|c|}{ Total } \\
\hline & \multicolumn{2}{|c|}{ >10 gigi } & \multicolumn{2}{|c|}{$6-10$ gigi } & \multicolumn{2}{|c|}{$<10$ gigi } & & \\
\hline & $\mathrm{n}$ & $\%$ & $\mathrm{n}$ & $\%$ & $\mathrm{n}$ & $\%$ & $\mathrm{n}$ & $\%$ \\
\hline 60 & 3 & 10 & 2 & 6,7 & 0 & 0,0 & 5 & 16,7 \\
\hline 61 & 0 & 0,0 & 1 & 3,3 & 0 & 0,0 & 1 & 3,3 \\
\hline 62 & 2 & 6,7 & 1 & 3,3 & 0 & 0,0 & 3 & 10,0 \\
\hline 63 & 6 & 20,0 & 1 & 3,3 & 0 & 0,0 & 7 & 23,3 \\
\hline 64 & 2 & 6,7 & 0 & 0,0 & 0 & 0,0 & 2 & 6,7 \\
\hline 65 & 8 & 26,7 & 3 & 10,0 & 1 & 3,3 & 12 & 40,0 \\
\hline Total & 21 & 70,1 & 8 & 26,6 & 1 & 3,3 & 30 & 100,0 \\
\hline
\end{tabular}


Tabel 5. Distribusi jumlah gigi yang hilang berdasarkan jenis kelamin

\begin{tabular}{|c|c|c|c|c|c|c|c|c|}
\hline \multirow{3}{*}{$\begin{array}{c}\text { Jenis } \\
\text { kelamin }\end{array}$} & \multicolumn{6}{|c|}{ Jumlah gigi yang hilang } & \multirow{2}{*}{\multicolumn{2}{|c|}{ Total }} \\
\hline & \multicolumn{2}{|c|}{$>10$ gigi } & \multicolumn{2}{|c|}{$6-10$ gigi } & \multicolumn{2}{|c|}{$<10$ gigi } & & \\
\hline & $\mathrm{n}$ & $\%$ & $\mathrm{n}$ & $\%$ & $\mathrm{n}$ & $\%$ & $\mathrm{n}$ & $\%$ \\
\hline Laki-laki & 7 & 23,3 & 3 & 10 & 0 & 0,0 & 10 & 33,3 \\
\hline Perempuan & 14 & 46,7 & 5 & 16,7 & 1 & 3,3 & 20 & 66,7 \\
\hline Total & 21 & 70,0 & 8 & 26,6 & 1 & 3,3 & 30 & 100,0 \\
\hline
\end{tabular}

Tabel 6. Distribusi responden berdasarkan status gizi menggunakan IMT

\begin{tabular}{ccc}
\hline Status gizi & n & $\begin{array}{c}\text { Persentae } \\
(\%)\end{array}$ \\
\hline Gizi lebih & 12 & 40,0 \\
Gizi normal & 18 & 60,0 \\
Gizi kurang & 00 & 00,0 \\
Total & 30 & 100 \\
\hline
\end{tabular}

Hasil penelitan selanjutnya menggunakan pemeriksaan status gizi berdasarkan usia. Tabel 7 menunjukkan bahwa lansia berusia 65 tahun merupakan jumlah terbesar pada kategori status gizi normal sebanyak 8 orang $(26,6 \%)$ dan untuk kategori status gizi lebih sebanyak 4 orang $(13,3 \%)$.
Tabel 8 menunjukkan bahwa lansia perempuan merupakan jumlah terbesar pada kategori status gizi normal sebanyak 13 orang $(43,3 \%)$ sedangkan lansia lakilaki dengan kategori status gizi lebih sebanyak 5 orang $(16,7 \%)$.

Tabel 9 menunjukkan responden dengan kehilangan $>10$ gigi yang memiliki status gizi normal berjumlah 13 orang dan responden dengan kehilangan $<6$ gigi yang memiliki gizi normal berjumlah 1 orang. Hasil uji statistik terhadap kedua variabel menggunakan chi-square mendapatkan nilai $P \quad 0,597(\mathrm{p}>0,05)$ yang menunjukkan tidak terdapat hubungan antara jumlah kehilangan gigi dan status gizi.

Tabel 7. Distribusi status gizi berdasarkan usia

\begin{tabular}{ccccccccc}
\hline \multirow{2}{*}{ Usia } & \multicolumn{9}{c}{ Status gizi } & \multicolumn{2}{c}{ Total } \\
\cline { 2 - 7 } & \multicolumn{2}{c}{ Gizi kurang } & \multicolumn{2}{c}{ Gizi normal } & \multicolumn{2}{c}{ Gizi lebih } & & \\
\cline { 2 - 6 } & $\mathrm{n}$ & $\%$ & $\mathrm{n}$ & $\%$ & $\mathrm{n}$ & $\%$ & $\mathrm{n}$ & $\%$ \\
\hline 60 tahun & 0 & 0,0 & 2 & 6,7 & 3 & 10 & 5 & 16,7 \\
61 tahun & 0 & 0,0 & 2 & 6,7 & 0 & 0,0 & 2 & 6,7 \\
62 tahun & 0 & 0,0 & 1 & 3,3 & 2 & 6,7 & 3 & 10,0 \\
63 tahun & 0 & 0,0 & 4 & 13,3 & 2 & 6,7 & 6 & 20,0 \\
64 tahun & 0 & 0,0 & 1 & 3,3 & 1 & 3,3 & 2 & 6,6 \\
65 tahun & 0 & 0,0 & 8 & 26,7 & 4 & 13,3 & 12 & 40,0 \\
Total & 0 & 0,0 & 18 & 60,0 & 12 & 40,0 & 30 & 100,0 \\
\hline
\end{tabular}

Tabel 8. Distribusi status gizi berdasarkan jenis kelamin

\begin{tabular}{|c|c|c|c|c|c|c|c|c|}
\hline \multirow{3}{*}{$\begin{array}{c}\text { Jenis } \\
\text { kelamin }\end{array}$} & \multicolumn{6}{|c|}{ Status gizi } & \multirow{2}{*}{\multicolumn{2}{|c|}{ Total }} \\
\hline & \multicolumn{2}{|c|}{ Gizi kurang } & \multicolumn{2}{|c|}{ Gizi normal } & \multicolumn{2}{|c|}{ Gizi lebih } & & \\
\hline & $\mathrm{n}$ & $\%$ & $\mathrm{n}$ & $\%$ & $\mathrm{n}$ & $\%$ & $\mathrm{n}$ & $\%$ \\
\hline Laki-laki & 0 & 0,0 & 5 & 16,7 & 5 & 16,7 & 10 & 33,4 \\
\hline Perempuan & 0 & 0,0 & 13 & 43,3 & 7 & 23,3 & 20 & 66,6 \\
\hline Total & 0 & 0,0 & 18 & 60,0 & 12 & 40,0 & 30 & 100,0 \\
\hline
\end{tabular}


Pioh, Siagian, Tendean: Hubungan antara jumlah kehilangan gigi ...

Tabel 9. Hubungan antara kehilangan gigi dengan status gizi berdasarkan IMT

\begin{tabular}{ccccc}
\hline \multirow{2}{*}{ Kehilangan gigi } & \multicolumn{3}{c}{ Status gizi } & \multirow{2}{*}{ P value } \\
\cline { 2 - 4 } & Gizi kurang & Gizi normal & Gizi lebih & \\
> 10 gigi & 0 & 13 & 8 & \\
6-10 gigi & 0 & 4 & 4 & 0,597 \\
< 10 gigi & 0 & 1 & 0 & \\
Total & 0 & 18 & 12 & \\
\hline
\end{tabular}

\section{BAHASAN}

Berdasarkan penelitian yang dilakukan di Desa Kolongan Atas II Kecamatan Sonder terhadap lansia dengan usia 60-65 tahun didapatkan distribusi responden terbanyak yaitu lansia dengan usia 65 tahun (40\%) (Tabel 3). Seiring dengan meningkatnya pembangunan bidang kesehatan, maka terjadi pula peningkatan Usia Harapan Hidup (UHH) yang menyebabkan proporsi populasi berusia lebih dari 60 tahun bertambah. ${ }^{3}$

Pada proses penuaan banyak terjadi perubahan yang dapat memengaruhi struktur rongga mulut yaitu perubahan struktur dan fungsi gigi, rahang dan jaringan mulut lainnya. Salah satu perubahan yang mengakibatkan tanggalnya gigi yaitu perubahan jaringan periodontal yang umum ditemukan pada lansia. Tanggalnya gigi pada lansia juga dapat disebabkan oleh karies gigi. Hal ini sejalan dengan penelitian yang dilakukan oleh Harsono dan Prabowo bahwa kehilangan gigi dapat disebabkan oleh penyakit periodontal, karies gigi, dan trauma. ${ }^{17}$

Berdasarkan hasil penelitian diperoleh responden terbanyak berjenis kelamin perempuan yaitu sebesar $66,6 \%$, sedangkan responden laki-laki sebesar 33,4\% (Tabel 4). Hal ini disebabkan karena jumah penduduk perempuan lebih banyak dibandingkan dengan laki-laki sesuai dengan $\mathrm{AHH}^{5}$

Hasil pemeriksaan kehilangan gigi pada lansia yang berusia 60-65 tahun di Desa Kolongan Atas II Kecamatan Sonder, mendapatkan hasil terbanyak kehilangan gigi berdasarkan kategori kehilangan $>10$ gigi yaitu sebesar 70\% (Tabel 5). Sebagian besar kehilangan gigi pada lansia terjadi di bagian posterior rahang atas dan bawah dengan jumlah kehilangan gigi yaitu $>10$ gigi, sedangkan pada bagian anterior jumlah kehilangan $<6$ gigi. Dari hasil wawancara dengan responden diperoleh bahwa sebagian besar lansia mendapatkan kesulitan saat mengunyah makanan karena banyak gigi yang hilang di bagian posterior tetapi tidak memengaruhi kualitas makanan yang dikonsumsi.

Tabel 4 menunjukkan kehilangan gigi berdasarkan usia dengan responden terbanyak pada usia 65 tahun dengan kategori kehilangan $>10$ gigi sebesar 26,6\% sedangkan pada lansia berusia 63 tahun dengan kategori kehilangan $>10$ gigi sebesar $20 \%$. Seiring dengan bertambahnya usia, prevalensi kehilangan gigi akan semakin besar. Kehilangan gigi tentunya dapat mengurangi kenyamanan dalam mengunyah sehingga lansia akan membatasi jenis makanan yang dikonsumsi. Berdasarkan hasil penelitian Prabhu et al. ${ }^{15}$ kehilangan gigi paling banyak terjadi pada bagian posterior yaitu gigi molar dan premolar. Kehilangan gigi paling banyak terjadi di rahang bawah dibandingkan rahang atas. Hal ini disebabkan karena gigi molar permanen rahang bawah lebih dahulu erupsi sehingga memungkinkan persentase karies yang tinggi dan kemungkinan lebih cepat dicabut. ${ }^{14,18}$

Tabel 5 menunjukkan kehilangan gigi berdasarkan jenis kelamin dengan jumlah responden tertinggi yaitu pada lansia perempuan dengan kehilangan $>10$ gigi sebanyak 14 orang $(46,6 \%)$ dan pada responden jenis kelamin laki-laki dengan kehilangan $>10$ gigi sebanyak 7 orang $(23,3 \%)$. Penelitian yang dilakukan oleh Cobert et al. menyatakan bahwa perempuan memiliki sedikit risiko penyakit periodontal tetapi besar kemungkinan perempuan mengalami risiko karies yang dapat menye- 
babkan kehilangan gigi. ${ }^{19}$

Pemeriksaan dan penilaian status gizi berdasarkan IMT terhadap responden lansia di Desa Kolongan Atas II Kecamatan Sonder menunjukkan bahwa walaupun terdapat kehilangan gigi yang cukup banyak sebagian besar lansia masih memiliki status gizi normal $(60 \%)$ (Tabel 9). Hasil penelitian ini tidak selaras dengan penelitian oleh Zoraya et al. ${ }^{20}$ yang menyatakan bahwa lansia umumnya mengalami kemunduran fisik, salah satunya ditandai dengan kehilangan gigi, yang dapat menyebabkan gangguan fungsi pengunyahan dan berakibat asupan nutrisi berkurang dan memengaruhi status gizi.

Hasil penelitian ini mendapatkan bahwa lansia usia 65 tahun memiliki jumlah responden terbesar dengan status gizi normal sebesar 26,6\%. Hasil yang diperoleh selaras dengan penelitian oleh Bertha $^{21}$ dimana jumlah tertinggi responden berada pada status gizi normal. Semakin meningkatnya usia lansia maka semakin banyak terjadi penurunan fungsi fisik/ fisiologis terkait fungsi pencernaan seperti menurunnya kemampuan indra pengecapan, perasa, penciuman, tanggalnya gigi, kesulitan menelan dan mengunyah yang dapat memengaruhi status gizi, tetapi dalam penelitian ini masih banyak lansia memiliki status gizi normal yang dibuktikan dalam penelitian ini berdasarkan pemeriksaan IMT.

Berdasarkan jenis kelamin didapatkan bahwa lansia perempuan memiliki jumlah responden terbesar dengan status gizi normal (43,3\%) (Tabel 10). Hasil penelitian ini selaras dengan penelitian yang dilakukan oleh Ibrahim ${ }^{11}$ yang melaporkan bahwa responden tertinggi yaitu lansia perempuan dengan status gizi normal. Jenis kelamin merupakan faktor internal yang menentukan status gizi. Laki-laki cenderung membutuhkan gizi yang lebih banyak dibandingkan perempuan untuk membantu proses metabolisme. ${ }^{11}$

Hasil uji chi-square menunjukkan bahwa tidak terdapat hubungan bermakna antara jumlah kehilangan gigi dan status gizi lansia $(P=0,597)$. Hasil penelitian ini sejalan dengan penelitian yang dilakukan oleh Ridwan ${ }^{22}$ yang menyatakan bahwa tidak terdapat hubungan bermakna antara kehilangan gigi dengan status gizi lansia, namun berbeda dengan penelitian yang dilakukan oleh Hermawati ${ }^{17}$ di Jakarta yang melaporkan adanya hubungan bermakna anatra kedua variabel.

Pada penelitian ini sebagian besar responden mengalami kehilangan gigi $>10$ dengan responden yang masuk dalam kategori status gizi normal berjumlah 13 orang sedangkan responden yang paling sedikit mengalami kehilangan gigi $<6$ gigi berjumlah 1 orang dengan status gizi normal. Berdasarkan hasil yang diperoleh maka dapat dilihat bahwa kelompok lansia ini tidak begitu terganggu dengan masalah pengunyahan sehingga masih bisa mendapatkan asupan gizi yang lebih baik. Hal ini mugkin disebabkan karena responden masih memiliki sejumlah gigi di rongga mulut sehingga para lansia juga bisa sesekali mengonsumsi makanan yang keras dan juga yang berserat dan berkalori tinggi. Makanan sehari-hari yang dapat memberikan zat gizi yang dibutuhkan untuk fungsi normal tubuh terdiri dari karbohidrat, protein, lemak, vitamin, mineral, dan air. ${ }^{23}$

\section{SIMPULAN}

Berdasarkan hasil penelitian ini dapat disimpulkan bahwa tidak terdapat hubungan bermakna antara kehilangan gigi dengan status gizi pada lansia di Desa Kolongan Atas II Kecamatan Sonder.

\section{SARAN}

Disarankan kepada para lansia di Desa Kolongan Atas II Kecamatan Sonder untuk tetap memperhatikan asupan makanan dengan mengonsumsi makanan mengandung gizi seimbang sehingga dapat mempertahankan nutrisi dan status gizi agar tetap baik. Selain itu, sebaiknya gigi yang hilang digantikan dengan gigi tiruan.

Disarankan kepada pemerintah Desa agar memrogramkan penyuluhan kesehatan gigi dan mulut yang rutin baik oleh Dinas Kesehatan maupun instansi terkait, karena kehilangan gigi dapat menyebabkan kurang 
atau ketidakpercayaan diri dan memengaruhi kemampuan mengunyah.

\section{DAFTAR PUSTAKA}

1. Sari DS, Ariana YMD, Ermawati T. Hubungan pengetahuan kesehatan gigi mulut dengan status kebersihan rongga mulut pada lansia. Jurnal IKESMA. 2015:11(1):44-51.

2. Sutikno E. Hubungan antara fungsi keluarga dan kualitas hidup lansia [Tesis]. Kediri: Institut Ilmu Kesehatan Bhakti Wiyata; 2011.

3. Amran Y, Kusumawardani R, Supriyatiningsih $\mathbf{N}$. Determinan asupan makanan usia lanjut. Kesmas. 2012: 6(6):255-60.

4. Kementrian Kesehatan Republik Indonesia, Pelayanan dan peningkatan kesehatan usia lanjut; 2015. [cited 2018 March]. Available from: http://www.depkes.go. $\mathrm{id} /$ article/view/15052700010/pelayanan -dan-peningkatan-kesehatan-usialanjut.html

5. Badan Pusat Statistik Manado. Jumlah penduduk kota manado menurut umur 2011-2016. Available from: https manadokota.bps.go.idstatictable201708 18198jumlah-penduduk-kota-manadomenurut-kelompok-umur-20112016.html

6. Nganro R. Status gizi manula pada pemakaian ggi tiruan penuh di Kota Makassar [Skripsi]. Makassar: Fakultas Kedokteran Gigi Universitas Hasanudin; 2014.

7. Jayasingha RM, Tilakarante A, Amarasena N, Mack F, Anandamoorthy $T$. Impact of marginal contact of removable acrylic partial dentures on periodontal parameters. International Journal of Research in Medical and Health Sciences. 2013;1(3):1-11.

8. Harsono V, Prabowo H. Implan dental sebagai perawatan alternatif untuk rehabilitasi kehilangan sebuah gigi. Jurnal. Dentofasial. 2012;11(3):170-3.

9. Watuma F, Wowor MP, Siagian KV. Gambaran rongga mulut pada lansia pemakai gigi tiruan sebagian lepasan di panti werda kabupaten Minahasa. eG. 2015;3(1):94-99.

10. Sari KI, Darjan M, Nur'aeny N, Rakhmilla LE. Hubungan antara kehilangan gigi dengan fungsi kognisi dan fungsi memori pada lansia penghuni Panti Sosial Tresna Werdha (PTSW) Senjawari Kota Bandung. Majalah Kedokeran Gigi Indonesia. 2017;3(2):61-8.

11. Ibrahim HS. Hubungan faktor-faktor yang mempengaruhi kebutuhan gizi dengan status gizi lanjut usia di UPTD Rumoh Seujahtera Geunaseh Sayang Banda Aceh. Idea Nursing Jurnal. 2012; 3(2):51-62.

12. Siregar RD, Arneliwati, Nauli FA. Hubungan status gizi terhadap kejadian anemia pada lansia. Jurnal Online Mahasiswa Program Studi Ilmu Keperawatan Universitas Riau. 2014; 1(1):1-10.

13. Thalib B, Ramadhani KN, Asmawati. Status gizi dan kualitas hidup pada lansia pengguna gigitiruan penuh di Kota Makassar. Jurnal MKMI. 2015; 11(1):44-9.

14. Senjaya AA. Gigi lansia. Jurnal Skala Husada. 2016;13(1):72-80.

15. Prabhu N, Kumar S, D' souza M, Hedge V. Partial edentulousness in $\mathrm{s}$ rural population based on Kennedy's classification: An epidemiological study. J Prosthodont. 2009;9:18-23.

16. Almatsier S. Prinsip Dasar Ilmu Gizi. Jakarta: Gramdia, 2001; p. 3.

17. Hermawati I. Hubungan kehilangan gigi dengan status gizi lansia di PTSW Budi Mulia 03 Margaguna Jakarta Selatan [Skripsi]. Jakarta: UIN Syarif Hidayatullah; 2017.

18. World Health Organization. Database on body mass index. [online] [cited 2018 Jun 3]. Available from: URL: http://apps.who.int/bmi/index.jsp

19. Zoraya M, Tjahjati E, Saleh S. Pengaruh pemakaian gigi tiruan lengkap terhadap status gizi lansia. Tahun 2013. Available from: http://sipus.simaster. ugm.ac.id/digilib/index.php?mod=pene litian_detail\&sub=PenelitianDetail\&act =view\&typ=html\&buku_id=7326\&oby ek id $=4$

20. Setiati S, Istanti R, Andayani R, Kuswardhani RA, Aryana IG, Putu ID, et al. Cut-off of anthropometry measurement and nutritional status among elderly outpatient in Indonesia: multi-centre study. Acta Med Indones. 2010;42(4):224-30. 
21. Bertha AA. Pengaruh kehilangan gigi sebagian terhadap status gizi manula di Kota Makassar [Skripsi]. Makassar: Fakultas kedokteran Gigi Universitas Hasanudin; 2014.

22. Ridwan M. Hubungan kehilangan gigi dengan status gizi pada lansia di Panti Werdha Salib Putih Salatiga. Jurnal Program Studi Keperawatan Stikes
Ngudi Waluyo Ungaran. 2015:1-10.

23. Mainake MB. Hubungan antara tingkat asupan energi dengan status gizi lansia di Kelurahan Mapanget Barat Kecamatan Mapanget Kota Manado. Manado: Fakultas Kesehatan Masyarakat Universitas Sam Ratulangi, 2012: p. 1-11. 